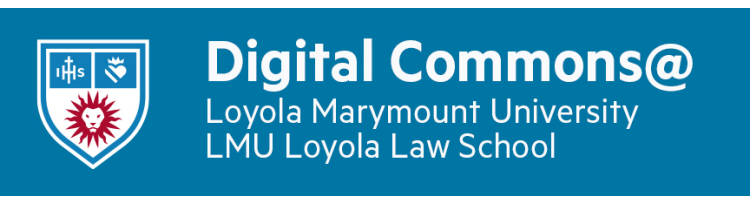

Journal of Catholic Education

\title{
Alternative Teacher Education and Professional Preparedness: A Study of Parochial and Public School Contexts
}

John L. Watzke

Follow this and additional works at: https://digitalcommons.Imu.edu/ce

\section{Recommended Citation}

Watzke, J. L. (2005). Alternative Teacher Education and Professional Preparedness: A Study of Parochial and

Public School Contexts. Journal of Catholic Education, 8 (4). http://dx.doi.org/10.15365/joce.0804042013

This Focus Section Article is brought to you for free with open access by the School of Education at Digital Commons at Loyola Marymount University and Loyola Law School. It has been accepted for publication in Journal of Catholic Education by the journal's editorial board and has been published on the web by an authorized administrator of Digital Commons at Loyola Marymount University and Loyola Law School. For more information about Digital Commons, please contact digitalcommons@lmu.edu. To contact the editorial board of Journal of Catholic Education, please email JCE@nd.edu. 


\section{ALTERNATIVE TEACHER EDUCATION AND PROFESSIONAL PREPAREDNESS: A STUDY OF PAROCHIAL AND PUBLIC SCHOOL CONTEXTS}

JOHN L. WATZKE

University of Notre Dame

As staffing in Catholic $K-12$ schools has transitioned to a predominantly lay teaching corps over the past 50 years, a parallel process of secularization has taken place in teacher education programs at Catholic colleges and universities. The tradition of teaching as vocation in the formation of vowed religious has been replaced by standard programs of educational foundations, course work, and field experiences with a primary emphasis on the issues and needs of public schools. Many factors contribute to this focus in Catholic higher education: financial concerns; teacher candidate preference; state laws; lack of proximity, affiliation, or experience with Catholic schools. Many programs function under a mission to prepare teachers for any school setting, public, private, or parochial, and view an intentional focus on Catholic education as limiting or debilitating to the professional development of teacher candidates. This article asks the question: Can an alternative teacher education program based in service to Catholic education prepare teachers to be effective in both parochial and secular settings? The study investigated the professional preparedness of M.Ed. in-program teacher candidates $(\mathrm{n}=163)$ working in Catholic schools and program graduates $(\mathrm{n}=137)$ and these graduates' principals $(\mathrm{n}=112)$ working in either Catholic or public schools. Results of the administration of a professional preparedness inventory indicated teacher self-reported and principal reported rates at comparable levels to replicated national surveys. Comparison of graduate and principal responses by school context indicated no statistically significant difference for overall measures of preparedness. Specific areas of significant difference were identified in the Catholic school context (higher preparedness rates in curriculum and instruction and questioning and discussion skills) and public school context (higher rates of preparedness in encouraging critical thinking, reflective practice, and use of technology). Discussion focuses on the Catholic school context as a viable alternative for the preparation of teachers for multiple school contexts. 


\section{INTRODUCTION}

Tmagine the reduction of the teaching force in the United States by $80 \%$ 1 within a span of 4 decades. How would the nation react to ensure the best education for our children? Undoubtedly, national commissions would be formed, initiatives undertaken, and a transitional plan implemented to address the pending crisis. Leaders would emerge with whom, by their very names, we would associate the reform vision (Mann, Dewey, Shanker, to name a few examples from history). Catholic education in the United States has experienced such dramatic change. One of the very foundations that contributed to the identity and staffing of these schools, the system of formation and professional development of vowed religious (nuns and brothers) and clergy (priests) as teachers, is virtually absent from contemporary schools. Although the shift from religious and clergy to a lay teaching force has unfolded since the 1960s, there has been no national plan for this transition, no systematic program to form lay teachers for work in Catholic schools, and an increasing reliance on public education as a model for the professional preparation of teachers for these schools. This article investigates the potential of alternative teacher education based in the Catholic school tradition to serve as a foundation for the formation and professional preparedness of teachers. It begins with a review of changes in staffing and teacher preparation for Catholic schools amid renewed support for the role teachers play in the formation of Catholic identity. Next, a study is presented that replicates prior research on teacher preparedness to investigate the professional development of teacher candidates enrolled in a program based in Catholic education. The ensuing discussion focuses on the Catholic school context as a viable alternative for the preparation of teachers for both parochial and public schools.

\section{A CRITICAL PERIOD IN CATHOLIC EDUCATION}

Until the 1960s, the teaching force serving Catholic K-12 schools traditionally had been comprised of vowed religious and clergy (brothers, nuns, priests) who were associated with the identity of these schools. Their various traditions and orders date back to the early settlement of the Americas and form a fundamental component of a history that has served Catholic and non-Catholic, poor and wealthy, ethnically and culturally diverse students (Bryk, Lee, \& Holland, 1993; Cook, 2002; Youniss \& Convey, 2000). In 1950, religious staffed $90.1 \%$ of Catholic K-12 schools. In its historical peak in 1960, when enrollments numbered 5,253,791 in 12,893 schools, staffing of religious and clergy had decreased to 73.8\% (McDonald, 2004, p. 3). Over consecutive decades, this percentage markedly decreased without a planned or sustainable system for preparing lay educators for Catholic 
education. Due to multiple religious, political, and societal changes in American Church traditions and schools (Dolan, 1985; Youniss \& Convey, 2000), their presence in the classrooms of Catholic schools has nearly vanished. By 2000, $93 \%$ of teachers were lay. This percentage crept to $94.9 \%$ in 2003 among the nearly 8,000 schools now serving over 2,400,000 students (McDonald, 2004, p. 3). There currently exists no comprehensive means for the preparation of teachers dedicated to Catholic education similar in mission and scope to the religious tradition.

Despite an on-going demographic shift to laity, the Catholic Church has continued to stress the importance of schools to Catholic identity and the teachers that serve them: "Of the educational programs available to the Catholic community, Catholic schools afford the fullest and best opportunity to realize the...purpose of Christian education among children and young people[: message, community, service, worship]" (National Conference of Catholic Bishops [NCCB], 1972, p. 28). A series of documents and publications released by the Vatican and the NCCB throughout the last decade (Cook, 2002; Watzke, 2002) underscore the importance of the vocation of Catholic school teacher as an apostolic and public ministry. These include In Support of Catholic Elementary and Secondary Schools (NCCB, 1990), Principles for Educational Reform in the United States (NCCB, 1995), and The Catholic School on the Threshold of the Third Millennium (Congregation for Catholic Education, 1998). The publications not only recognize the contribution of the institution of the school to Catholic identity, they also stress the central role of teachers to meet the moral and spiritual needs of students.

One answer to the question of teacher preparation for Catholic schools may lie in the approximately 170 teacher education programs in institutions of Catholic higher education. What has been the commitment of these programs to the preparation of teachers? Surveys of mission and curriculum have found an intense focus on public education, to the exclusion of educational foundations, field-teaching experiences, and courses reflecting the history and traditions of Catholic education (National Catholic Educational Association, 1977; Watzke, 2002). Two thirds of these programs' faculty have no prior experience in Catholic schools (as students, teachers, or administrators) and over $40 \%$ report no required curricular component serving Catholic schools (Watzke, 2002). One third of these programs make explicit a secular mission in the preparation of K-12 teachers and another two thirds do not provide related field-teaching experiences (Watzke, 2002). Not surprisingly, a low percentage of teacher education graduates teach in Catholic schools, when compared to the proportion of employment opportunities in parochial schools (Watzke, 2002). With few direct pathways leading to a teaching career in Catholic schools, dioceses 
have carried the burden, implementing programs of orientation and professional development for newly hired teachers who come from a range of backgrounds. As high as one third of elementary and secondary teachers in Catholic schools are not state certified nor hold a degree in their main field of teaching. Nearly half of all religion teachers are uncertified in any subject (Cook, 2002). Despite stabilization and a moderate increase in student enrollments through the 1990s (National Center for Education Statistics [NCES], 2000), a sustained and purposeful model for the preparation of teachers for Catholic schools remains elusive.

We see preparing teachers who can be effective in any setting as our mission, with a particular emphasis on urban schools....We...support the idea of preparing teachers who can work with all children, within any specific type of school or school system. (Watzke, 2002, p. 145)

This quote comes from an education department chair at a Catholic college. It summarizes the predominant "one-size-fits-all" mission of programs across the country, in which public education provides an efficient focus to prepare teachers for a variety of contexts: public, Catholic, private. Besides limited faculty experience and curricular components focused on Catholic schools, economic pressures and philosophical differences affect the mission of these teacher education programs. Many view a secular mission as best serving its education student clientele, who are oriented toward competitive and higher paying public school jobs. Others believe that providing curricular components, particularly field-teaching experiences, oriented toward Catholic schools is debilitating to their students' development as teachers - in essence, "sheltering" students from the realities of teaching (Watzke, 2002, p. 147). Despite research (Hunt, Joseph, \& Nuzzi, 2002) and an ecclesiastical call supporting linkage between mission, curriculum, and subsequent teaching careers in Catholic education, higher education is not united in this goal. With the transition to laity nearly complete, a critical period characterizes the state of teacher education for Catholic K-12 schools. Will higher education play a deliberate and purposeful role in the emergence of a new pathway to a career in Catholic education?

\section{CAN ALTERNATIVE EDUCATION SERVE THE CATHOLIC MISSION?}

A deliberate decision has been made by many Catholic colleges and universities to prepare teachers through a program of secular foundations and curricular experiences. Catholic identity and educational traditions are subjugated to a philosophy that seeks to serve society through public educa- 
tion. One education department chair put it this way: "We do not offer special programs or courses for teaching in Catholic schools. We do not distinguish between preparing students for Catholic schools and public schools [italics added]" (Watzke, 2002, p. 146). Such a mission is meant to prepare teachers for all school contexts, without a focused awareness of the needs and challenges in parochial education. Particularly absent from such a programmatic mission are the history and foundations of Catholic education, which continue to impact American society today: a place of refuge; a place of community and service through a qualitatively different education; an alternative for the underserved and, often, forgotten by society; a history of reciprocal innovation and learning, not in competition, but in cooperation with public education (Bryk et al., 1993; McGreevy, 2003; Walch, 1996).

The variety of schools, colleges, and universities founded and sustained through this history is striking: from schools that continue to serve minority and entirely non-Catholic students to those which are being transformed and enriched by a growing Latino population; from the growth in suburban schools as a traditionally Catholic working class prospered and advanced in educational achievement to a recommitment and reopening of urban schools in cities such as Memphis to serve emergent needs of these communities; from access to higher education for generations historically denied such opportunities because of religion or race to nationally recognized colleges and universities which continue a tradition of social justice among diverse student populations. Despite the recent merges and closings of parish schools as demographic shifts present challenges and opportunities to diocesan schools nationally, the United States Catholic schools remain the largest private school system in the world.

In 1994, the University of Notre Dame founded the Alliance for Catholic Education (ACE) and a teacher education program with an intentional mission in service to Catholic education. The ACE Master's of Education (M.Ed.) program at Notre Dame prepares teacher candidates in a 2-year and 2-summer program of graduate study and full-time teaching in service to Catholic schools based on three programmatic pillars: professional teaching, community, spirituality. Several programmatic aspects with regard to the mission of this program are important. First, the M.Ed. program is oriented toward the needs and challenges facing Catholic K-12 schools. Although graduate students complete an accredited academic program leading to state certification, the program is based in Catholic identity and educational mission. Second, graduate students, known as ACE teachers, serve as full-time teachers of record in diocesan schools as part of an alliance between the university and dioceses. ACE teachers fill immediate and on-going needs in faculty and staffing of schools while graduates 
transition into careers in education. Currently, ACE graduates are certified to teach in 41 states. Finally, the alliance makes possible a multi-layered and long-term program of support for teacher professional development focused on the interests of the schools, ACE teachers, and their students (see Figure 1). This alliance also makes possible a unique contribution to the field of alternative teacher education. The program is grounded in best practices: long-term professional development; field-based learning; focus on content-specific pedagogy; use of student assessment for improved teacher practice (Hiebert, Gallimore, \& Stigler, 2002; Wideen, MayerSmith, \& Moon, 1998). The graduate program has grown exponentially in the past decade to enroll 170 graduate students annually serving 26 dioceses and 100 schools. Growth continues as the programmatic model is being replicated at 12 colleges and universities in partnership with Notre Dame.

\section{Entrance into Program \\ - BA/BS or higher in content area \\ - Service and teaching experience \\ - Entrance review teams, essays, and interview \\ - "April Retreat" - new ACE teacher cohort, school mentors and administrators, ACE M.Ed. faculty and staff}

\footnotetext{
Summer Sessions (2)

University Supervisor

- summer session instructor

- establishes professional development plan

- second summer conference revision of this plan

Content Professor/s

- research and pedagogy

- performance-based assignments

Clinical Faculty

- content master teacher

- formative support

- assigned to summer courses

Clinical Supervisor (first summer)

- summer practicum

- master teacher

Associate Director - M.Ed. graduate

- community and school relations

- workshops, courses, conference

- facilitation of community living preparation

Chaplains

- spiritual formation support

Health Professional Liaison

- counsels and provides referrals
}

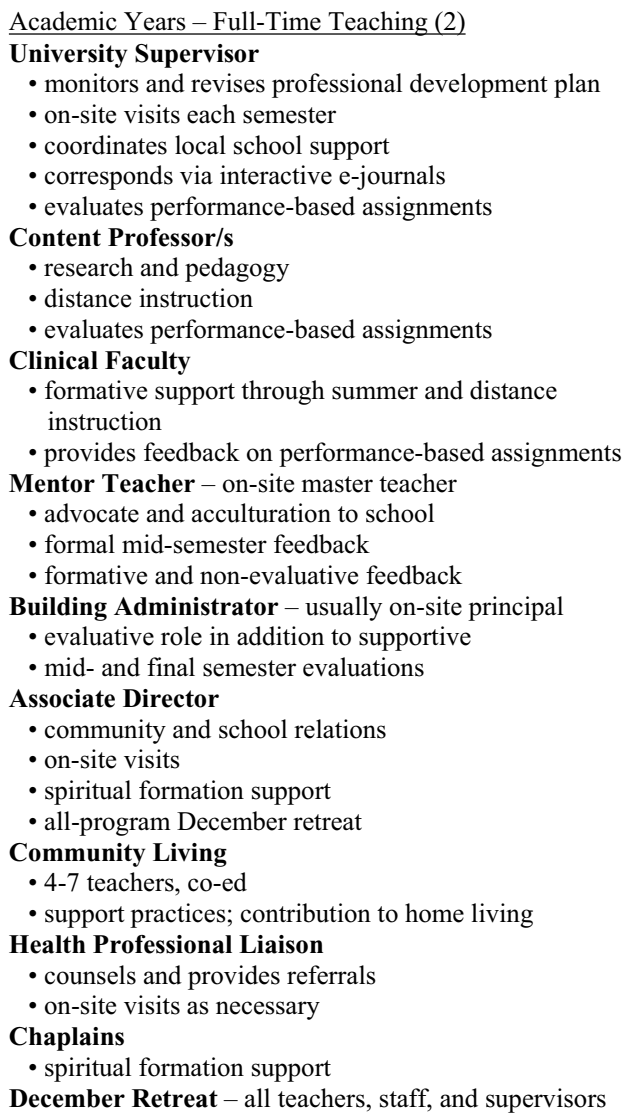

Figure 1. Layers of support during the 2-year ACE M.Ed. Program: Professional, community, and spiritual personnel. 
As an alternative teacher education program with a distinct mission in service to Catholic education, the ACE M.Ed. represents the inverse of the predominant model in place in Catholic higher education. The uniqueness of this program is challenged on two fronts. First, as an alternative teacher education program, one in which teachers are placed in classrooms before completing certification, it is open to criticism of the quality of teaching that takes place in the classroom and the preparedness of teachers who graduate (Chin, Young, \& Floyd, 2004; Darling-Hammond, 2000, 2002). Second, as a program with a primary focus on Catholic education, it is challenged by a widely-held view in Catholic higher education that only a secularly-based program prepares teachers for work in diverse school contexts and enhances graduates' professional development and employability (Watzke, 2002). Can an alternative teacher education program based in service to Catholic education prepare teachers to be effective in both parochial and secular settings? The study presented in this article sought to answer this question through the lens of the professional preparedness of its graduates across the multiple contexts in which they teach.

\section{ALTERNATIVELY-PREPARED TEACHERS IN CATHOLIC AND PUBLIC SCHOOLS}

\section{BACKGROUND}

Teacher professional preparedness has been the focus of a series of studies comparing self-reported teacher perceptions across various school contexts and teacher education programmatic models (Darling-Hammond, Chung, \& Frelow, 2002; Imbimbo \& Silvernail, 1999; NCES, 2001; Silvernail, 1998). This study utilized common instrumentation and domains of professional preparedness to gauge ACE teacher professional development. In addition to ACE M.Ed. graduates, an expansion of the original study design included responses from the principals of graduates who are teaching in both Catholic and public schools. Four research questions framed this study:

1. How do ACE teachers perceive their professional preparedness as both in-program and post-program full-time teachers?

2. How do these perceptions compare nationally to beginning teachers who have graduated from traditional and alternative teacher education programs?

3. Do the perceptions of preparedness differ for ACE M.Ed. graduates teaching in Catholic and public schools?

4. Do the perceptions of the principals of ACE M.Ed. graduates differ in terms of teacher preparedness according to Catholic and public school context? 


\section{SURVEY INSTRUMENTATION}

The survey instrument was originally developed jointly by New Visions for Public Schools and the National Commission on Teaching and America's Future's Urban Initiative to study beginning teacher preparedness (Silvernail, 1998). The instrument consisted of 40 items designed to measure professional preparedness in areas of teacher practices considered supportive to student learning. These items were identified from an analysis of standards produced by the National Board for Professional Teaching Standards and the Interstate New Teacher Assessment and Support Consortium (INTASC; Darling-Hammond, 1992; Imbimbo \& Silvernail, 1999). Respondents rated preparedness on a Likert-scale ranging from 1 , not at all prepared, to 5, very well prepared (Darling-Hammond et al., 2002). Silvernail (1998) conducted item analysis to establish item reliability and factor analysis to identify five summative domains measured by the survey items: preparedness to promote student learning; preparedness to teach critical thinking and social development; preparedness to use technology; preparedness to understand learners; preparedness for on-going development of instructional leadership. These domains and associated survey items can be found in Appendix B. Five items did not load into these factors. Four are listed under "additional areas" and one under "overall preparedness." An additional open-ended question, designed to elicit commentary from teachers and principals about the professional preparedness of graduates, was included in the present study's survey instrument.

\section{SUBJECTS}

The subjects represent several groupings of ACE teachers and school principals based on different definitions of "beginning teacher." Studies utilized for comparative analysis define beginning teachers as those with 3 or fewer years of full-time teaching experience (Darling-Hammond et al., 2002; NCES, 2001). There is substantial evidence in the literature on beginning teaching that identifies the first 3 years as a challenging period that is characterized by attrition from the profession (Feiman-Nemser, 2001). Since the ACE M.Ed. program incorporates full-time teaching into its programmatic model, two definitions were developed to investigate preparedness within a cross-sectional study design. The first definition is termed "in-program" beginning ACE teachers. These teachers are engaged in their first and second year of full-time teaching in Catholic schools and graduate studies at the University of Notre Dame. Two program cohorts, ACE 10 (first-year teachers) and ACE 9 (second-year teachers) were identified as subjects of study. The second definition is termed "post-program" beginning teachers. These are graduates of the ACE M.Ed. program who 
have been teaching full-time in Catholic or public schools for 3 or fewer years. Three cohorts, ACE 6, 7, and 8, meet this criterion.

In order to fully investigate research questions one, two, and four, the study also included as subject all remaining graduated ACE teachers from cohorts 1 through 5, engaged in full-time teaching in Catholic and public schools for a complete accounting of all program graduates since its inception in 1994. Beginning with the ACE 5 cohort, the University of Notre Dame initiated programmatic transition toward a permanent administrative and faculty unit, housed on campus in the Institute for Educational Initiatives, which would oversee a graduate degree change from Master of Arts in Teaching (M.A.T) to the M.Ed. This transition included revision of the academic program and an intensification of the 2-year collaboration between faculty, ACE teacher, and diocesan schools. Inclusion of all cohorts in the study represents a complete accounting of graduates and the purposeful grouping of graduates by programmatic organizational period.

Demographic information for each cohort is summarized in Appendix A. The ACE 10 cohort $(n=88)$ consists of in-program teachers who had completed the first academic summer session, which included a practicum field experience, and 4 months of first-year teaching. The ACE 9 cohort ( $n$ =75) consists of in-program teachers who had completed two academic summer sessions, 1 year of full-time teaching and graduate studies, and an additional 4 months of second-year full-time teaching. Post-program cohorts 1-8 $(n=137)$ represent graduates who are currently teaching in Catholic and public schools. Finally, the principals of these graduates are represented in Appendix B $(n=112)$. The principals were surveyed as part of the triangulation strategy to verify trends in the strengths and weaknesses in preparation.

As subjects of study, the in-program and post-program ACE teachers represent a self-selected population characterized by the ideals of social justice, spirituality growth as experienced through teaching, high academic achievement, and prior volunteerism related to education. Prospective teachers come from over 120 colleges and universities and enter into a selection process that is characterized by a competitive 5:1 applicant to acceptance ratio. This competition is heightened by the prospect of a fullyfunded graduate degree upon acceptance. Applicants to the ACE program must complete written essays, which address the pillars of teaching, community, and spirituality. Each applicant is personally interviewed by a selection committee that further explores experiences related to these pillars. The transcript of each prospective teacher is carefully reviewed to ensure state licensure requirements for content course completion are satisfied. Teachers selected for the program must pass Praxis teacher exams in their content area of certification during the first summer session. Selected 
ACE teachers have an average cumulative undergraduate GPA of 3.45 across majors in liberal studies and the social and hard sciences and average 2.5 years of volunteer experience in schools during their undergraduate studies. A deliberate attempt is made to balance the gender of each cohort as a means to encourage men to enter teaching and to establish coeducational home communities. A 50\% male/female split for each cohort is achieved annually. The ACE program is one of the most ethnically diverse education programs nationally, with over $16 \%$ of its graduates self-identified as minority (National Education Association, 2003).

\section{SCHOOL CONTEXT}

Catholic K-12 education serves a bimodal distribution of students consisting of a low-income, primarily minority, population in urban schools on the one hand and a wealthy, primarily White, student population enrolled in suburban schools on the other (Hallinan, 2002). The schools in which inprogram and post-program ACE teachers are employed differ in terms of minority percentage, socio-economic status of students, and urbanicity, but generally serve the first category of schools. In-program teachers work in schools with a significantly large minority student population $(50.4 \%$ of the students on average). The students of these schools receive federally subsidized lunch at a rate of $20.6 \%$. The majority of these schools (70.3\%) are in an urban setting. Graduates of the ACE M.Ed. gravitate toward schools within similar contexts. Over $40 \%$ of schools served by graduated ACE teachers enroll a predominantly minority student population and $20 \%$ of schools' students are from low-income families. Nearly two thirds of these schools are located in an urban setting.

\section{SURVEY ADMINISTRATION AND RESPONSE RATES}

The survey was administered to the in-program groups, cohorts 9 and 10 , in December of 2003 during an all-program retreat. This application captured ACE teachers' perceptions of professional preparedness at the midpoint of the academic year when their focus was on full-time teaching. The second two groups, ACE M.Ed. graduates and their principals, were surveyed in two waves. First, a January 2004 mass e-mail survey was sent to 208 graduates identified on the ACE alumni database to be actively teaching in Catholic and public schools. Four follow-up e-mail surveys took place through March 2004. The second wave consisted of an April 2004 email survey of the principals of responding ACE alumni. Four follow-up email surveys were conducted through May 2004.

The response rates for the four groupings are summarized in Appendix A. As the frequency and response rates for each cohort are compared in this 
appendix, it should be noted that cohort size has increased each consecutive year of the ACE M.Ed. program. Later cohorts are expected to be more heavily represented in terms of overall numbers. A $100 \%$ response rate was achieved with ACE cohorts 9 and 10 due to the advantage of collective survey administration at the annual retreat.

The overall response rate for the graduated cohorts $1-8$ was $70.6 \%$. Initially, 208 surveys were distributed. Fourteen were returned as discontinued e-mail addresses. Of the 194 functioning addresses that remained, 137 graduates responded. Appendix A details frequency and response rates by cohort, gender, grade level, and Catholic or public school setting. Since earlier cohorts consisted of fewer teachers, aggregate data are more easily compared by the following collapsed categories: all graduated cohorts (18 ); graduates with 4 or more years of teaching experience (1-5); graduates with 1 to 3 years of teaching experience (6-8). Comparing these categories, overall response rates are near the $70 \%$ level. In terms of gender, men are more highly represented in the returned surveys of those graduates teaching for the longest period of time (cohorts 1-5) while balanced for cohorts 6-8. The greatest number of ACE graduates teach in the 9-12 high school grade range $(n=94)$, followed by elementary school $(n=54)$ and middle school $(n=46)$. Response rates by level for all graduates favored the high school grade range where $76.6 \%$ of graduates surveyed responded compared to $66.7 \%$ and $63 \%$ from the elementary and middle school grade ranges respectfully. This response trend held for the two aggregate groupings of cohorts. In terms of response rates for graduates in Catholic $(n=$ 106) and public schools $(n=31)$, a higher proportion of public school teachers responded across all aggregate groupings. ACE graduates continue to teach in Catholic schools at over three times the rate of those transitioning into public schools. This trend held across all aggregate groups. Although counts of graduates self-reported as minorities were low across individual cohorts $(n=21)$, this $15.3 \%$ minority response is consistent with the minority percentage of ACE M.Ed. graduates over the history of the ACE program.

Responding principals numbered 112 out of the 137 surveyed, for an $81.8 \%$ response rate. Comparing the principal response rates across categories, comparable rates are evidenced with the exception of two trends: lower response rates were noted from the principals of graduates who had 4 or more years of teaching experience and who were teaching at the elementary school level (66.7\%) and in Catholic schools (66.7\%). These response rates are much higher than the $33 \%$ rate reported in the original series of beginning teacher surveys upon which the instrumentation was replicated (Darling-Hammond et al., 2002). 
Data analysis. Several steps in data analysis addressed the research questions. First, to compare perceptions of professional preparedness across the in-program and post-program ACE teacher cohorts, descriptive comparison and two-tailed $t$-tests of independent means were conducted. Since cell counts were low for earlier cohorts, analysis of all individual cohorts was limited to descriptive comparison of item means in order to provide an accounting of reported levels of preparedness with years of teaching experience. It was expected that the ACE teachers would report higher levels as they progressed through the graduate program and years of full-time teaching experience.

However, organizational change in the academic program characterized the delineation of graduates with 3 or fewer years (cohorts 6-8) and those with 4 or more years (cohorts 1-5) of post-graduate teaching experience. Differences between the means of these two graduated aggregate groupings were expected to be nuanced. In order to gauge whether mean differences supported the expectation that additional years of teaching experience were associated with significant gains in preparedness, $t$-tests were conducted.

Next, to compare the professional preparedness of ACE teachers to those of beginning teachers from traditional and alternative programs, data from replicated and similar studies were gathered, arranged in tabular format, and utilized to inform a descriptive comparison of level of professional preparedness on a national level. As cited earlier, two studies were identified, which explored the issue of preparedness through survey instrumentation and identical or similar items and scales. Darling-Hammond, Chung, and Frelow (2002) studied beginning teachers in New York City (NYC). This research focused on the urban school context. The subjects were teachers with 3 or fewer years of experience who were "traditionally prepared" $(n=1,307)$, graduates of state accredited teacher education programs and state certified upon entering full-time teaching, and "alternatively prepared" ( $n=48)$, individuals who entered full-time teaching on an emergency credential (Teach for America) or while enrolled in a master's program (Peace Corps and Teacher Opportunity Corps; Darling-Hammond et al., 2002, p. 289). The survey used in the NYC study served as a model for the instrument utilized in the present study of ACE teachers and graduates.

The second data source comes from a study of teacher preparation and professional development conducted by the National Center for Education Statistics (2001). A nationally representative sample $(n=732)$ of beginning teachers with 3 or fewer years of experiences was surveyed on preparedness and participation in professional development activities (NCES, 2001). Unlike the NYC survey, this study utilized a reduced Likert scale and number of survey items. The rating scales for the present study and the NCES study each ranged from not at all prepared to very well prepared. 
However, the NCES scale consisted of four points, rather than five. Additionally, the NCES study included only nine survey items on preparedness. Responses were reported as percentages by response category according to a four-point rating scale.

Both the NYC and NCES instruments drew from areas of professional preparedness identified by INTASC for item development. This provided a common reference for comparison. Whereas the present survey of ACE teachers replicated the exact instrument from the NYC study, items on the NCES study included similar, but alternative wording. For example, the NCES survey included an item asking teachers with 3 or fewer years of experience to rate their preparedness "to address the needs of students from diverse cultural backgrounds." The survey of ACE teachers and graduates asked teachers to rate their preparedness "to understand how students' family and cultural backgrounds may influence learning." Neither the NYC nor the NCES surveys reported results that could be compared using more advanced statistical methods beyond descriptive reporting. Both surveys sampled different populations and school contexts. However, each provides comparative trend results and nationally reported findings to inform the discussion on teacher preparedness and alternative teacher preparation.

Additional analysis compared the self-reported and principal-reported rates of graduates' professional preparedness by school context. Two-tailed independent means $t$-tests, with school context (Catholic or public) serving as the independent variable and teacher or principal item mean as the dependent variable, were conducted. The two post-program populations were ACE teacher cohorts 1-8 (Catholic $n=106$ and public $n=31$ ) and responding principals (Catholic $n=84$ and public $n=28$ ). Research on teacher education practices in Catholic higher education has presented conflicting views on the efficacy of the Catholic school context for teacher professional preparedness. The null hypothesis for each of these tests was that there would be no significant difference between level of professional preparedness of ACE M.Ed. graduates by school context as reported by the teachers and their principals.

The final analysis step focused on the textual data elicited by the openended written response prompt. This item invited teachers and principals to include commentary on professional preparedness. Twenty-five of the returned teacher surveys and 15 returned principal surveys included written responses. Textual data were read by the author and a research assistant, categorized into emergent themes, and reviewed for representative passages to be used in the interpretation of the survey results. This enhanced the triangulation of data (ACE teacher in-program and graduated cohorts, and principal graduated cohorts) by providing a narrative viewpoint in the development of a composite description of professional preparedness. 


\section{RESULTS AND DISCUSSION}

\section{PROFESSIONAL PREPAREDNESS OF IN-PROGRAM AND POST-PROGRAM TEACHERS}

The results of the first data analysis step are summarized in Appendix B. Descriptive statistics for each of the in-program and post-program cohort groupings are displayed by increasing years of teaching experience. Not surprisingly, teacher professional preparedness increases with experience, with the ACE teachers engaged in their first year of teaching and graduate studies associated with the lowest means. Across the four groupings, several trends become apparent. First, even during their first year, ACE teachers (cohort 10) report being adequately prepared for the overall demands of teaching as indicated by the mean on Item $40(M=3.2727, S D=.6734)$. This overall measure is supported by similar ratings on the remaining 39 items. Second, from cohort 10 to 9, representing in-program teachers separated by a year of teaching and graduate studies, there is a marked increase in the means of items under the domain "understanding learners." Items 11 and 13, which target student developmental influences and special learning needs, indicate a particularly large growth in preparedness. First-year cohort 10 reported preparedness between the poorly and adequately prepared levels on these two items while the second-year cohort 9 reported levels between the adequately and well prepared levels. Finally, the teachers reported being under-prepared across all cohorts to teach students who have limited proficiency in English effectively (Item 14).

Comparing the two post-program groupings, higher levels of preparedness were reported by the more recently graduated cohorts (6-8). Statistical analysis identified six items in which levels were significantly higher for this group. Two items related to the domain "promoting student learning," three to "understanding learners," and one related to new English language learners. These graduates report being very well-prepared to plan instruction $(p=.035, M=4.2963, S D=.7322)$ and to choose teaching strategies $(p=$ $.024, M=4.0617, S D=.5989$ ) to meet student needs. They also reported similar levels of preparedness to draw from their understanding of students' environment outside the school ( $p=.011, M=4.3457, S D=.6921)$, to work with parents and families ( $p=.011, M=4.0000, S D=.8660)$ and to identify and address special learning needs or difficulties ( $p=.001, M=3.5556$, $S D=.8515$ ) in order to affect student learning. This more recently graduated grouping also reported being better prepared to teach in ways that support new English learners $(p=.001)$, although the mean level fell between the poorly and adequately prepared range $(M=2.7284, S D=1.1293)$. 


\section{COMPARISON TO TEACHERS FROM TRADITIONAL AND ALTERNATIVE EDUCATION PROGRAMS}

Appendix B and Table 1 present comparative data from the identified national studies on beginning teacher preparedness. This comparative analysis is not intended to suggest the effectiveness of one teacher education program over another. Rather, it provides a national frame of reference for the discussion of trends in professional preparedness utilizing common survey instrumentation across different teaching and school contexts. In the case of the NYC survey, the context is urban and public. In their study of over 1,000 beginning teachers, Darling-Hammond and her colleagues found significant differences between the preparedness of teachers who were certified (program prepared) and those teachers working on emergency certification and/or engaged in teacher education studies (alternative route). Program-prepared teachers were better prepared on all items with 18 of the 40 item differences statistically significant. These means are presented in the last two columns of Appendix B. Comparing the means of the two NYC teaching groups to in-program ACE teachers and post-program beginning teachers, several basic trends are observed. First-year ACE teachers (cohort 10) report comparable levels of preparedness to the NYC program-prepared teachers. Second-year ACE teachers (cohort 9) report higher levels across all items except the single item referring to "new English learners." The graduated ACE M.Ed. cohorts engaged in their first 3 years of beginning teaching (cohorts 6-8) report markedly higher levels of preparedness than the NYC program-prepared teachers. These trends are heightened when comparisons are made with the alternative route NYC teachers. Across all beginning teacher groupings, the most marked differences in preparedness are observed in the five items related to the use of technology in teaching, in which in-program and post-program ACE teachers report rates nearly a full point higher on the Likert scale. Preparedness to teach in ways that support new learners of English represents the single item across all program means in which the NYC teachers report higher levels, reported between the poorly prepared and adequately prepared levels in that study.

Unlike the urban context of the NYC study, the NCES study provided the opportunity to compare data trends to a nationally representative sample of beginning teachers. Results are summarized in Table 1. Comparing items across the two definitions of beginning teachers used to group in-program and post-program teachers becomes important. Although in-program ACE teachers engaged in their first or second year of teaching and graduate studies report being "adequately" or better prepared on the nine items, proportionally fewer report the highest levels of preparedness when com- 
Table 1

Item Comparisons From K-12 ACE and NCES Beginning Teacher Surveys

\begin{tabular}{|c|c|c|c|c|c|}
\hline Survey Items & \multicolumn{5}{|c|}{ Scales and Percentages } \\
\hline \multicolumn{6}{|l|}{ Overall Preparedness } \\
\hline $\begin{array}{l}\text { Overall, how well prepared did you feel when you } \\
\text { first started teaching? }\end{array}$ & $\begin{array}{l}\text { Very well } \\
\text { prepared }\end{array}$ & $\begin{array}{c}\text { Well } \\
\text { prepared }\end{array}$ & $\begin{array}{l}\text { Adequately } \\
\text { prepared }\end{array}$ & $\begin{array}{l}\text { Poorly } \\
\text { prepared }\end{array}$ & $\begin{array}{l}\text { Not at all } \\
\text { prepared }\end{array}$ \\
\hline 0.5 years $\mathrm{ACE} 10(n=88)$ & 4.5 & 26.1 & 61.4 & 8.0 & 0.0 \\
\hline 1.5 years $\mathrm{ACE} 9(n=75)$ & 5.3 & 33.3 & 45.3 & 16.0 & 0.0 \\
\hline$\leq 3$ years $\mathrm{ACE} 6-8(n=81)$ & 32.1 & 54.3 & 9.9 & 2.5 & 1.2 \\
\hline
\end{tabular}

How well prepared do you feel to meet the overall demands of your teaching assignment?
Very well Moderately well Somewhat well Not at all prepared prepared prepared prepared

$\leq 3$ years $\operatorname{NCES}(n=732)$

49.0

43.0

8.0

Classroom Order

How well prepared were you to maintain an orderly, purposeful learning environment?

Very well

prepared

$$
\begin{array}{r}
0.5 \text { years ACE } 10(n=88) \\
1.5 \text { years ACE } 9(n=75) \\
\leq 3 \text { years ACE } 6-8(n=81)
\end{array}
$$

How well prepared do you feel to maintain order and discipline in the classroom?

$\begin{array}{rrrrr}12.5 & 45.5 & 36.4 & 5.7 & 0.0 \\ 26.7 & 45.3 & 24.0 & 4.0 & 0.0 \\ 48.1 & 46.9 & 3.7 & 1.2 & 0.0\end{array}$

Very well Moderately well Somewhat well Not at all prepared prepared prepared prepared

$\begin{array}{lll}51.0 & 37.0 & 10.0\end{array}$

Cooperative Learning

How well prepared were you to engage students in

Very well

prepared

Well

prepared

Adequately
prepared

Poorly
prepared

\section{Not at all} learning?

$$
\begin{array}{r}
0.5 \text { years ACE } 10(n=88) \\
1.5 \text { years ACE } 9(n=75) \\
\leq 3 \text { years ACE } 6-8(n=81)
\end{array}
$$

$$
38.6
$$

39.8
30.7
11.1

How well prepared do you feel to implement new methods of teaching (e.g., cooperative learning)?

Very well prepared
Moderately well prepared
Somewhat well prepared
Not at all prepared

Curriculum

How well prepared were you to develop curriculum that builds on students' experiences, interests, and abilities?

$\begin{array}{lcccc}\begin{array}{l}\text { Very well } \\ \text { prepared }\end{array} & \begin{array}{c}\text { Well } \\ \text { prepared }\end{array} & \begin{array}{c}\text { Adequately } \\ \text { prepared }\end{array} & \begin{array}{c}\text { Poorly } \\ \text { prepared }\end{array} & \begin{array}{c}\text { Not at all } \\ \text { prepared }\end{array}\end{array}$

$$
\begin{array}{r}
0.5 \text { years ACE } 10(n=88) \\
1.5 \text { years ACE } 9(n=75) \\
\leq 3 \text { years ACE } 6-8(n=81)
\end{array}
$$

5.7
25.3
34.6

25.0
45.3
46.9

52.3
25.3
14.8

How well prepared do you feel to implement state or district curriculum?

Very well prepared
Moderately well prepared
Somewhat well prepared
Not at all prepared 
Table 1 (continued)

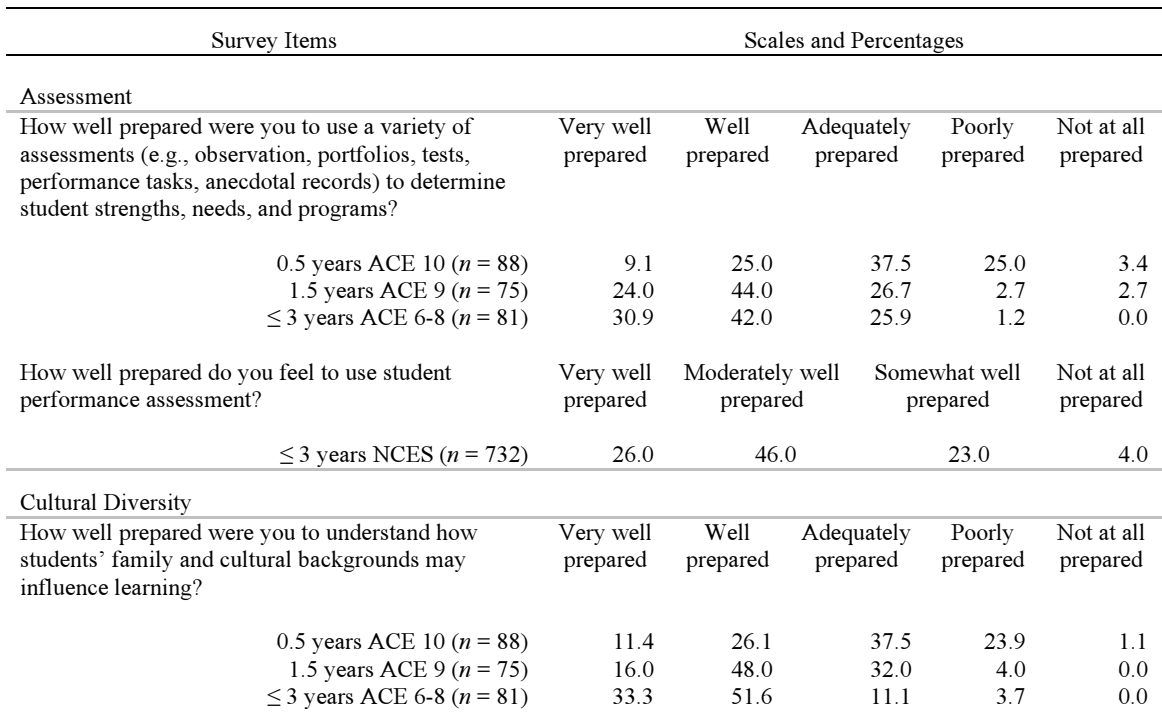

How well prepared do you feel to address needs of students from diverse cultural backgrounds?

Very well prepared
Moderately well prepared
Not at all prepared

$$
\leq 3 \text { years } \operatorname{NCES}(n=732)
$$

45.0

24.0

Student Disabilities

How well prepared were you to identify and address special learning needs and/or difficulties?

$\begin{array}{rrrrr}\begin{array}{c}\text { Very well } \\ \text { prepared }\end{array} & \begin{array}{c}\text { Well } \\ \text { prepared }\end{array} & \begin{array}{c}\text { Adequately } \\ \text { prepared }\end{array} & \begin{array}{c}\text { Poorly } \\ \text { prepared }\end{array} & \begin{array}{r}\text { Not at all } \\ \text { prepared }\end{array} \\ 0.0 & 10.2 & 33.0 & 48.9 & 8.0 \\ 1.3 & 37.3 & 42.7 & 14.6 & 3.0 \\ 12.3 & 42.0 & 34.6 & 11.1 & 0.0\end{array}$

Very well prepared
Moderately well prepared
Not at all prepared students with disabilities?

$\leq 3$ years $\operatorname{NCES}(n=732)$

$* 28.0$

$* 42.0$ prepared

English Language Learners

How well prepared were you to teach in ways that support English language learners?

Very well
prepare

$$
\begin{array}{r}
0.5 \text { years ACE } 10(n=88) \\
1.5 \text { years ACE } 9(n=75) \\
\leq 3 \text { years ACE } 6-8(n=81)
\end{array}
$$

How well prepared do you feel to address the needs of students with limited English proficiency?
Very well Moderately well Somewhat well Not at all prepared prepared prepared prepared 
Table 1 (continued)

\begin{tabular}{|c|c|c|c|c|c|}
\hline \multicolumn{2}{|l|}{ Survey Items } & \multicolumn{3}{|c|}{ Scales and Percentages } & \\
\hline \multicolumn{6}{|l|}{ Technology } \\
\hline $\begin{array}{l}\text { How well prepared were you to use technology to } \\
\text { increase student interest and learning? }\end{array}$ & $\begin{array}{l}\text { Very well } \\
\text { prepared }\end{array}$ & $\begin{array}{cr}\text { Well } & \text { Ade } \\
\text { prepared } & \text { pre }\end{array}$ & & $\begin{array}{l}\text { Poorly } \\
\text { prepared }\end{array}$ & $\begin{array}{l}\text { Not at all } \\
\text { prepared }\end{array}$ \\
\hline & & & & & \\
\hline & 9 & 41 & & & \\
\hline$\leq 3$ ye & & 30.9 & & 11.1 & \\
\hline $\begin{array}{l}\text { How well prepared do you feel to integrate education } \\
\text { technology? }\end{array}$ & $\begin{array}{l}\text { Very well } \\
\text { prepared }\end{array}$ & $\begin{array}{l}\text { Moderately well } \\
\text { prepared }\end{array}$ & & $\begin{array}{l}\text { what well } \\
\text { pared }\end{array}$ & $\begin{array}{l}\text { Not at all } \\
\text { prepared }\end{array}$ \\
\hline$\leq 3$ years $\operatorname{NCES}(n=732)$ & 23.0 & 41.0 & & 28.0 & \\
\hline \multicolumn{6}{|c|}{$\begin{array}{l}\text { Note. The three ACE beginning teacher cohort groupings consist of first- and second-year graduate students } \\
\text { who had completed one-half (ACE 10) and one and one-half years (ACE 9) of full-time teaching in } \\
\text { Catholic schools and graduate studies in fulfillment of a } 2 \text {-year M.Ed. program at the University of Notre } \\
\text { Dame and graduates of the program who had completed } 3 \text { or fewer years of full-time teaching (ACE 6-8) in } \\
\text { Catholic and public schools. The NCES beginning teachers represent a nationally representative sample of } \\
\text { teachers who had completed } 3 \text { or fewer years of full-time teaching. *Only those teachers in the NCES } \\
\text { survey who reported teaching students on Individual Education Plans (IEPs; } 86 \% \text { ) or with limited English } \\
\text { proficiency (42\%) were included in these analyses. Percentages may exceed } 100.0 \text { due to rounding. } \\
\text { Sources of NCES data: U. S. Department of Education, National Center for Education Statistics, Fast } \\
\text { Response Survey System, Teacher Survey on Professional Development and Training, 2000. From } \\
\text { National Center for Education Statistics. (2001). Teacher preparation and professional development: } 2000 \\
\text { (NCES 2001-088). Washington. DC: U. S. Department of Education. }\end{array}$} \\
\hline
\end{tabular}

pared to the NCES sample. On the other hand, graduates of the ACE M.Ed., who are engaged in the first 3 years of teaching in Catholic and public schools, report levels comparable to those of the beginning teachers of the NCES study. ACE M.Ed. graduates reported higher levels of preparedness in the areas of "assessment" (very well prepared $=30.9 \%$ ) and "cultural diversity" (very well prepared $=33.3 \%$ ). They reported lower levels in the areas of "student disabilities" and "English language learners," although the NCES responses were restricted to only those beginning teachers who reported teaching students on Individual Education Plans or with limited English proficiency (NCES, 2001, p. 35). The results confirm a trend of increasing preparedness through the in-program years of the ACE M.Ed. program, while graduates report high levels of preparedness during their initial years of teaching independent from the support structures of the program, equal or stronger than national comparisons.

\section{CATHOLIC AND PUBLIC SCHOOL CONTEXTS}

Recall that a common theme in defense of the predominant secular mission in the preparation of teachers by Catholic higher education is the induction to diverse professional and cultural experiences public schools afford teacher candidates. Since the mission of the ACE M.Ed. program is based in service to Catholic education, this presented an opportunity to test the validity of such a claim. If post-program graduates teach in both Catholic 
and public school contexts, is there a significant difference between their professional preparedness as self-reported and reported by their principals? The results of these analyses are presented in Appendix C.

The results identified limited differences between teachers' and principals' reporting on preparedness by school context. On the survey item addressing "overall preparedness" (Item 40), for example, teachers and principals across all contexts rated post-program teachers at the very well prepared level. In the case of teachers' responses, those in public schools reported two areas of professional preparedness at rates higher than those in Catholic schools: "helping students to learn to think critically and solve problems" and the ability to "evaluate and reflect on...practice to improve instruction." Although teachers in both school contexts reported being well prepared for these teaching practices, the means of teachers in public schools were significantly higher, contradicting the notion that these teachers would be under-prepared for the public school context.

Analysis of principal responses identified 10 statistically different means. Catholic school principals rated higher four items within the domain of "promoting student learning" related to curriculum selection, development, and assessment. Catholic school principals rated teachers at the well prepared level on these four items while public school principals rated their teachers at the adequately prepared level. A fifth item, development of "students' questioning and discussion skills," was also rated higher by the Catholic school principals $(M=3.7500, S D=.9432)$.

Public school principals rated higher teachers" ability to "evaluate and reflect on...practice to improve instruction" than their Catholic school counterparts. Consistent with the ACE teachers' self-ratings, teachers in public schools were rated between the well prepared to very well prepared levels to engage in reflective practices by their principals. Additionally, three items related to "using technology" were rated statistically higher by public school principals. These items related to the use of technology for student independent and group learning and for general communication needs. Item means ranged from adequately to well prepared.

\section{CONCLUSION}

The central question addressed in this study was whether a mission, counterintuitive in Catholic higher education, which places the Catholic school context as its core and that is alternative in design, can effectively prepare teachers for the profession. It explored teachers' and principals' perceptions of the preparedness of subjects as in-program and graduated teachers in Catholic and public schools. The study utilized comparable instrumentation and design from national studies as a common yardstick for this investigation. The results demonstrate that in-program ACE teachers perceive 
their preparedness across multiple professional dimensions at rates comparable to national samples of beginning teachers. Similarly, graduates of the ACE M.Ed. and their school principals rate their professional preparation at comparable or higher levels than the national samples. Finally, no significant difference was found on the global "overall preparedness" item as reported by graduated teachers and their principals in Catholic and public schools.

This study was designed to address the issue of teacher education for Catholic K-12 schools. The results and ensuing discussion highlight tangible themes related to teacher education program design and its impact on professional preparedness. The comparison of results to national studies utilizing common survey instrumentation was not intended to suggest the effectiveness of one teacher education program over another. Rather, it provided a generalized comparison of trends across differing teaching and school contexts. The results challenge the predominant approach in Catholic higher education that focuses on secular schools as a means to prepare teachers.

Future research might continue this line of inquiry to include more indepth qualitative study of graduates in parochial and public schools. Since a secular mission is, for many reasons, ingrained in current Catholic higher education engaged in the preparation of teachers, more must be understood about how these graduates transition into teaching careers in multiple contexts in order to strengthen the case for such alternative programs. Similarly, replication of the ACE model is currently underway in 11 institutions. Investigation into adaptations to the ACE model to fit existing teacher education programs or tracks is needed to better understand how teacher formation impacts on professional preparedness in ways that are unique to traditional teacher education.

Teacher education has traversed a historic path from religious to secular mission in Catholic higher education. The contemporary teaching force serving Catholic K-12 schools represents an amalgam of professional pathways to the school context, typically void of deliberate foundations, field experiences, and mission in service of Catholic education. Although the transition from a religious to lay teaching force was dramatic, it unfolded over a 40-year period and was recognized early as an inevitable trend. Alternative teacher education offers a unique opportunity to rethink the process of preparing teachers for Catholic schools. Drawing from the traditions of religious, particularly the formation of teaching communities with a common spiritual expression in faith, hope, and love in service to the world, a rethinking of teacher education may continue the history and traditions of Catholic education. Is such an alternative programmatic model challenging in its creation? Radical in educational mission? Controversial 
in the profession? The answer is "Yes." Just as the early development of the Catholic school system in the United States was met with criticism on social, political, and professional fronts, such may be the voice of detractors to an alternative model of teacher preparation with implications that are national in scope. It has been a decade since the founding of the ACE M.Ed. As similar programs are established and strengthened at other Catholic institutions of higher education, they will continue to impact the lives and careers of teachers and the students they serve, as this history continues.

\section{REFERENCES}

Bryk, A. S., Lee, V. E., \& Holland, P. B. (1993). Catholic schools and the common good. Cambridge, MA: Harvard University Press.

Chin, E., Young, J., \& Floyd, B. (2004, February). Placing beginning teachers in hard-to-staff schools: Dilemmas posed by alternative certification programs. Paper presented at the annual meeting of the American Association of Colleges of Teacher Education (AACTE), Chicago.

Congregation for Catholic Education. (1998). The Catholic school on the threshold of the third millennium. Catholic Education: A Journal of Inquiry \& Practice, 2(1), 4-14.

Cook, T. J. (2002). Teachers. In T. C. Hunt, E. A. Joseph, \& R. J. Nuzzi (Eds.), Catholic schools still make a difference: Ten years of research 1991-2000 (pp. 57-72). Washington, DC: National Catholic Educational Association.

Darling-Hammond, L. (1992). Teaching and knowledge: Policy issues posed alternative certification for teachers. Peabody Journal of Education, 67(3), 123-154.

Darling-Hammond, L. (2000). Solving the dilemmas of teacher supply, demand, and standards: How we can ensure a competent, caring, and qualified teacher for every child. New York: National Commission on Teaching and America's Future, Teachers College, Columbia University.

Darling-Hammond, L. (2002). Research and rhetoric on teacher certification: A response to "Teacher Certification Reconsidered." Education Policy Analysis Archives, 10(36).

Darling-Hammond, L., Chung, R., \& Frelow, F. (2002). Variation in teacher preparation: How well do different pathways prepare teachers to teach? Journal of Teacher Education, 53(4), 286-302.

Dolan, J. (1985). The American Catholic experience: A history from colonial times to the present. New York: Doubleday.

Feiman-Nemser, S. (2001). From preparation to practice: Designing a continuum to strengthen and sustain teaching. Teachers College Record, 103(6), 1013-1055.

Hallinan, M. T. (2002). Catholic education as a societal institution. Catholic Education: A Journal of Inquiry \& Practice, 6(1), 5-26.

Hiebert, J., Gallimore, R., \& Stigler, J. W. (2002). A knowledge base for the teaching profession: What would it look like and how can we get one? Educational Researcher, 31(5), 3-15.

Hunt, T. C., Joseph E. A., \& Nuzzi, R. J. (Eds.). (2002). Catholic schools still make a difference: Ten years of research 1991-2000. Washington, DC: National Catholic Educational Association.

Imbimbo, J., \& Silvernail, D. (1999). Prepared to teach? Key findings of the New York City Teacher Survey. New York: New Visions for Public Schools.

McDonald, D. (2004). United States Catholic elementary and secondary schools 2003-2004. Washington, DC: National Catholic Educational Association.

McGreevy, J. T. (2003). Catholicism and American freedom. New York: W. W. Norton \& Company.

National Catholic Educational Association. (1977, Summer). Survey report on teacher education in Catholic colleges and universities. Occasional Papers, 4-6. 
National Center for Education Statistics. (2000). Digest of education statistics, 1999 (NCES 2000-031). Washington, DC: U. S. Department of Education.

National Center for Education Statistics. (2001). Teacher preparation and professional development 2000 (NCES 2001-088). Washington, DC: U. S. Department of Education.

National Conference of Catholic Bishops. (1972). To teach as Jesus did. A pastoral message on Catholic education. Washington, DC: United States Catholic Conference.

National Conference of Catholic Bishops. (1990). In support of Catholic elementary and secondary schools. Washington, DC: United States Catholic Conference.

National Conference of Catholic Bishops. (1995). Principles for educational reform in the United States. Washington, DC: United States Catholic Conference.

National Education Association. (2003). Status of the American public school teacher 2000-2001. Washington, DC: Author.

Silvernail, D. L. (1998). Findings from an initial analysis of the New York City Teacher Survey. New York: New Visions for Public Schools.

Walch, T. (1996). Parish school: American Catholic parochial education from colonial times to the present. New York: Crossroad.

Watzke, J. (2002). Teachers for whom? A study of teacher education practices in Catholic higher education. Catholic Education: A Journal of Inquiry \& Practice, 6(2), 138-165.

Wideen, M., Mayer-Smith, J., \& Moon, B. (1998). A critical analysis of the research on learning to teach: Making the case for an ecological perspective on inquiry. Review of Educational Research, 68(2), 130-178.

Youniss, J., \& Convey, J. (2000). Catholic schools at the crossroads. New York: Teachers College Press.

The author would like to thank Barnard Greene of the National Center for Education Statistics and Laurie Lewis of Westat for additional data analysis provided in Table 1.

John L. Watzke is Coordinator of Supervision for the Alliance for Catholic Education and Fellow in the Institute for Educational Initiatives at the University of Notre Dame. Correspondence concerning this article should be sent to Dr. John Watzke, University of Notre Dame, 112 Badin Hall, Notre Dame, IN 46556. 
Appendix A

Descriptive Statistics for Sent and Returned Teacher and Principal Surveys by Cohort: Gender of Teacher, School Level, Catholic or Public

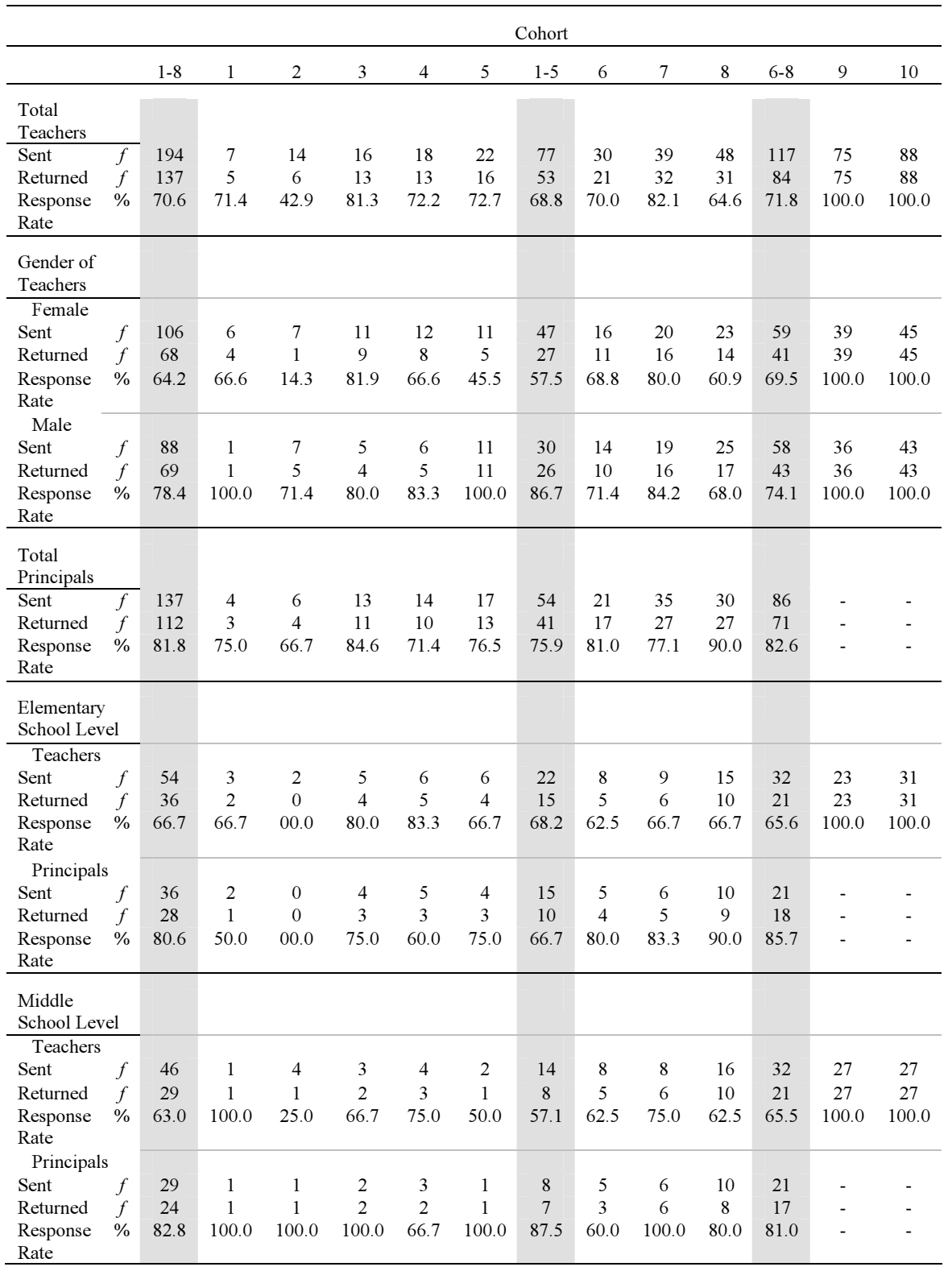


Appendix A (continued)

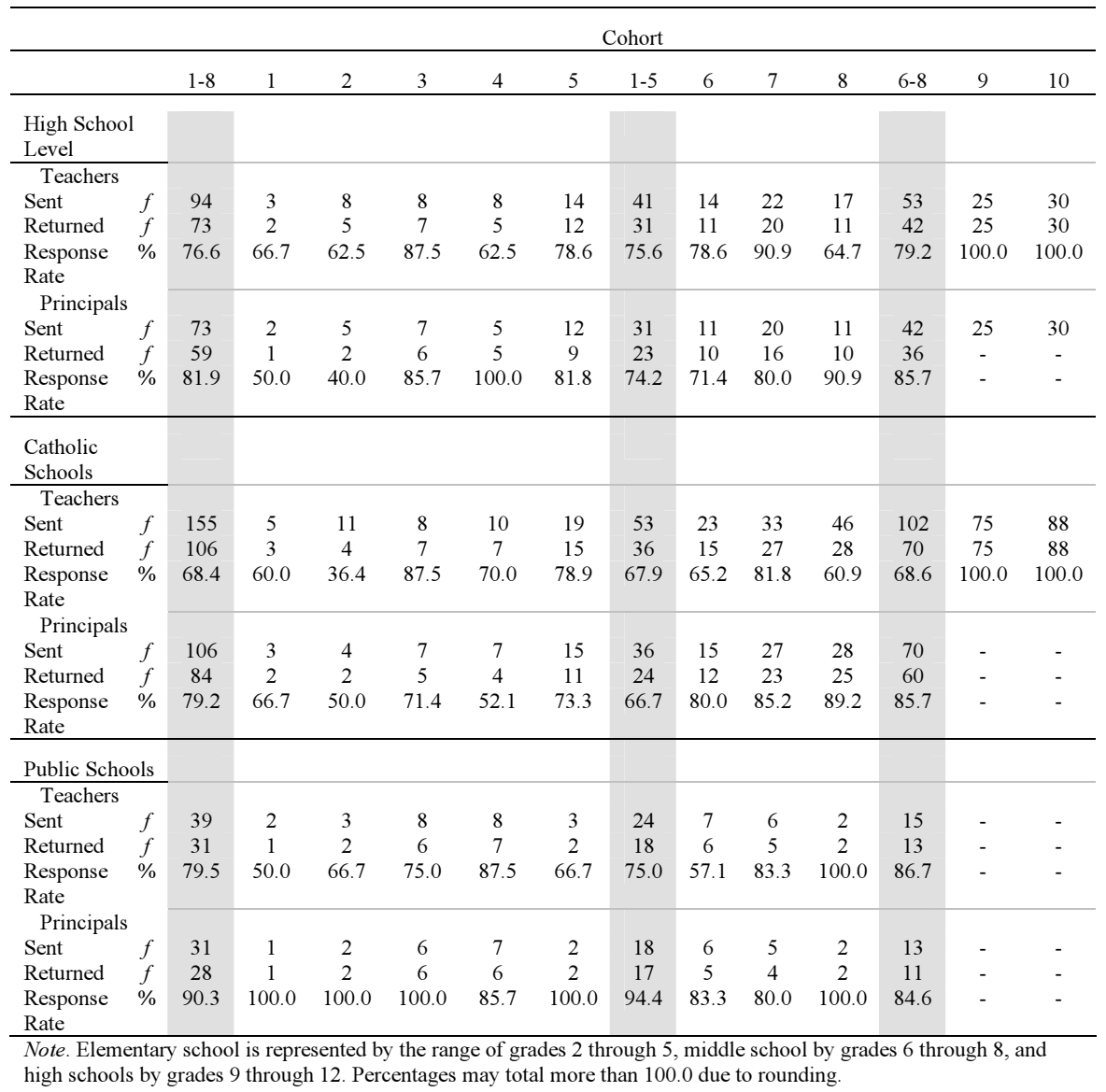




\section{Appendix B}

Professional Preparedness Ratings by Experience Levels and Program Type

\begin{tabular}{|c|c|c|c|c|c|c|c|}
\hline $\begin{array}{l}\qquad \text { Survey Item } \\
\text { When you first started teaching, } \\
\text { how well prepared did you feel to do the following }\end{array}$ & & $\begin{array}{l}\text { ACE } \\
0.5 \text { years } \\
\text { M.Ed. } \\
\text { Cohort } 10 \\
(N=88) \\
\end{array}$ & $\begin{array}{l}\text { ACE } \\
1.5 \text { years } \\
\text { M.Ed. } \\
\text { Cohort } 9 \\
(N=75)\end{array}$ & $\begin{array}{c}\text { ACE } \\
\leq 3 \text { years } \\
\text { Post M.Ed. } \\
\text { Cohorts 6-8 } \\
(N=81) \\
\end{array}$ & $\begin{array}{c}\text { ACE } \\
\geq 4 \text { years } \\
\text { Post M.Ed. } \\
\text { Cohort } 1-5 \\
(N=56) \\
\end{array}$ & $\begin{array}{l}\text { NYC } \\
\leq 3 \text { years } \\
\text { Program } \\
\text { Prepared } \\
(N=1,307)\end{array}$ & $\begin{array}{c}\text { NYC } \\
\leq 3 \text { years } \\
\text { Alternative } \\
\text { Route Teachers } \\
(N=48) \\
\end{array}$ \\
\hline \multicolumn{8}{|l|}{$\begin{array}{l}\text { Promoting Student Learning } \\
\text { 1. Teach subject matter concepts, knowledge, } \\
\text { and skills in ways that enable students to learn. }\end{array}$} \\
\hline & Mean & 3.5909 & 3.9333 & 4.3210 & 4.1887 & 3.6113 & 3.1875 \\
\hline & & .7214 & .7039 & .7387 & .7353 & $\mathrm{n} / \mathrm{a}$ & $\mathrm{n} / \mathrm{a}$ \\
\hline \multicolumn{8}{|l|}{$\begin{array}{l}\text { 2. Understand how different students in your } \\
\text { classroom are learning. }\end{array}$} \\
\hline & Mean & 3.0568 & 3.3867 & 3.8889 & 3.7358 & 3.2708 & 3.1521 \\
\hline & $S D$ & .8215 & .8036 & .7583 & .8582 & $\mathrm{n} / \mathrm{a}$ & $\mathrm{n} / \mathrm{a}$ \\
\hline \multicolumn{8}{|l|}{$\begin{array}{l}\text { 3. Set challenging and appropriate expectations } \\
\text { of learning and performance for students. }\end{array}$} \\
\hline & Mean & 3.3295 & 3.7200 & 4.2099 & 4.2453 & 3.3853 & 3.1875 \\
\hline & $S D$ & .8404 & .6273 & .6840 & .7572 & $\mathrm{n} / \mathrm{a}$ & $\mathrm{n} / \mathrm{a}$ \\
\hline \multicolumn{8}{|l|}{ 4. Help all students achieve high academic } \\
\hline & $S D$ & .8046 & .7565 & .6791 & .9072 & $\mathrm{n} / \mathrm{a}$ & $\mathrm{n} / \mathrm{a}$ \\
\hline \multicolumn{8}{|l|}{$\begin{array}{l}\text { 5. Develop curriculum that builds on students' } \\
\text { experiences, interests, and abilities. }\end{array}$} \\
\hline & Mean & 3.1932 & 3.9200 & 4.1235 & 3.9811 & 3.4326 & 3.000 \\
\hline & $S D$ & .7858 & .8180 & .7966 & .9092 & $\mathrm{n} / \mathrm{a}$ & $\mathrm{n} / \mathrm{a}$ \\
\hline \multicolumn{8}{|l|}{$\begin{array}{l}\text { 6. Evaluate curriculum materials for their } \\
\text { usefulness and appropriateness for your students. }\end{array}$} \\
\hline & Mean & 3.3295 & 3.4933 & 4.1358 & 3.8679 & 3.3676 & 3.1042 \\
\hline & $S D$ & .8404 & 1.0184 & .7706 & .9207 & $\mathrm{n} / \mathrm{a}$ & $\mathrm{n} / \mathrm{a}$ \\
\hline \multicolumn{8}{|l|}{$\begin{array}{l}\text { 7. Create discipline-based and interdisciplinary } \\
\text { curriculum. }\end{array}$} \\
\hline & Mean & 3.2386 & 3.5867 & 3.9506 & 3.7925 & 3.2822 & 2.9792 \\
\hline & $S D$ & .9222 & .9167 & .7400 & .9273 & $\mathrm{n} / \mathrm{a}$ & $\mathrm{n} / \mathrm{a}$ \\
\hline \multicolumn{8}{|l|}{$\begin{array}{l}\text { 8. Identify and obtain materials and use } \\
\text { community resources to create a multicultural } \\
\text { curriculum. }\end{array}$} \\
\hline & Mean & 2.9432 & 3.1467 & 3.6667 & 3.5472 & 3.1508 & 2.8085 \\
\hline & $S D$ & .9512 & .8806 & .9220 & .9916 & $\mathrm{n} / \mathrm{a}$ & $\mathrm{n} / \mathrm{a}$ \\
\hline \multicolumn{8}{|l|}{$\begin{array}{l}\text { 9. Use instructional strategies that promote } \\
\text { active student learning. }\end{array}$} \\
\hline & Mean & 3.3864 & 4.0400 & 4.4074 & 4.2830 & 3.5677 & 3.1458 \\
\hline & $S D$ & .7941 & .6666 & .6852 & .7937 & $\mathrm{n} / \mathrm{a}$ & $\mathrm{n} / \mathrm{a}$ \\
\hline \multirow[t]{2}{*}{$\begin{array}{l}\text { 16. Choose teaching strategies to meet } \\
\text { different student needs. }\end{array}$} & Mean & 3.1364 & 3.5600 & $* 4.0617$ & 3.7547 & 3.2816 & 3.0000 \\
\hline & $S D$ & .8330 & .6826 & .5989 & .8299 & $\mathrm{n} / \mathrm{a}$ & $\mathrm{n} / \mathrm{a}$ \\
\hline \multirow{2}{*}{$\begin{array}{l}\text { 25. Plan instruction by using knowledge of } \\
\text { learning subject matter, curriculum, and } \\
\text { student development. }\end{array}$} & & & & $p=.024$ & & & \\
\hline & $\begin{array}{r}\text { Mean } \\
S D\end{array}$ & $\begin{array}{r}3.4886 \\
.7271\end{array}$ & $\begin{array}{r}3.9600 \\
.7788\end{array}$ & $\begin{array}{r}* 4.2963 \\
.7322\end{array}$ & $\begin{array}{r}3.9245 \\
.8050\end{array}$ & $\begin{array}{r}3.4822 \\
\mathrm{n} / \mathrm{a}\end{array}$ & $\begin{array}{r}3.0652 \\
\mathrm{n} / \mathrm{a}\end{array}$ \\
\hline \multirow{3}{*}{$\begin{array}{l}\text { 28. Use a variety of assessments (e.g., } \\
\text { observation, portfolios, tests, performance } \\
\text { tasks, anecdotal records) to determine student } \\
\text { strengths, needs, and programs. }\end{array}$} & & & & $p=.035$ & & & \\
\hline & Mean & 3.1136 & 3.8400 & 4.0247 & 3.7170 & 3.1389 & 2.8333 \\
\hline & $S D$ & .9992 & .9159 & .7902 & .9277 & $\mathrm{n} / \mathrm{a}$ & $\mathrm{n} / \mathrm{a}$ \\
\hline \multirow[t]{2}{*}{$\begin{array}{l}\text { 29. Help students learn how to assess their } \\
\text { own learning. }\end{array}$} & Mean & 2.5682 & 3.0400 & 3.2963 & 3.1887 & 2.7880 & 2.4792 \\
\hline & $S D$ & .9321 & .8127 & .8283 & 1.0011 & $\mathrm{n} / \mathrm{a}$ & $\mathrm{n} / \mathrm{a}$ \\
\hline \multicolumn{8}{|l|}{$\begin{array}{l}\text { Teach Critical Thinking and Social Development } \\
\text { 17. Help students become self-motivated and } \\
\text { self-directed. }\end{array}$} \\
\hline & Mean & 3.0568 & 3.2400 & 3.9136 & $\begin{array}{r}3.9057 \\
8828\end{array}$ & 3.3982 & 3.0000 \\
\hline
\end{tabular}


Appendix B (continued)

\begin{tabular}{|c|c|c|c|c|c|c|c|}
\hline $\begin{array}{l}\qquad \text { Survey Item } \\
\text { When you first started teaching, } \\
\text { how well prepared did you feel to do the followin }\end{array}$ & & $\begin{array}{l}\text { ACE } \\
0.5 \text { years } \\
\text { M.Ed. } \\
\text { Cohort } 10 \\
(N=88) \\
\end{array}$ & $\begin{array}{l}\text { ACE } \\
\text { 1.5 years } \\
\text { M.Ed. } \\
\text { Cohort } 9 \\
(N=75) \\
\end{array}$ & $\begin{array}{l}\text { ACE } \\
\leq 3 \text { years } \\
\text { Post M.Ed. } \\
\text { Cohorts 6-8 } \\
(N=81)\end{array}$ & $\begin{array}{l}\text { ACE } \\
\geq 4 \text { years } \\
\text { Post M.Ed. } \\
\text { Cohort } 1-5 \\
(N=56) \\
\end{array}$ & $\begin{array}{c}\text { NYC } \\
\leq 3 \text { years } \\
\text { Program } \\
\text { Prepared } \\
(N=1,307) \\
\end{array}$ & $\begin{array}{c}\text { NYC } \\
\leq 3 \text { years } \\
\text { Alternative } \\
\text { Route Teachers } \\
\quad(N=48) \\
\end{array}$ \\
\hline \multicolumn{8}{|l|}{ 18. Develop a classroom environment that } \\
\hline \multirow[t]{2}{*}{ responsibility. } & Mean & 3.5341 & 3.8933 & 4.3333 & 4.2264 & 3.5926 & 3.0625 \\
\hline & $S D$ & .8963 & .7636 & .7071 & .8000 & $\mathrm{n} / \mathrm{a}$ & $\mathrm{n} / \mathrm{a}$ \\
\hline \multicolumn{8}{|l|}{$\begin{array}{l}\text { 19. Develop students' questioning and } \\
\text { discussion skills. }\end{array}$} \\
\hline & Mean & 3.6477 & 3.7733 & 4.1235 & 3.9245 & 3.4881 & 3.1702 \\
\hline & $S D$ & .7118 & .8940 & .7311 & .7808 & $\mathrm{n} / \mathrm{a}$ & \\
\hline \multicolumn{8}{|l|}{$\begin{array}{l}\text { 20. Engage students in cooperative group } \\
\text { work as well as independent learning. }\end{array}$} \\
\hline & Mean & 3.4773 & 3.8000 & 4.1975 & 4.1887 & 3.5866 & 3.0208 \\
\hline & $S D$ & .8301 & .7884 & .7318 & .7610 & $\mathrm{n} / \mathrm{a}$ & $\mathrm{n} / \mathrm{a}$ \\
\hline \multicolumn{8}{|l|}{$\begin{array}{l}\text { 21. Use effective verbal and nonverbal } \\
\text { communication strategies to guide student } \\
\text { learning and behavior. }\end{array}$} \\
\hline & Mean & 3.7614 & 4.3200 & 4.3704 & 4.1887 & 3.5235 & 3.3125 \\
\hline & $S D$ & .7878 & 1.3295 & .6412 & .8334 & $\mathrm{n} / \mathrm{a}$ & $\mathrm{n} / \mathrm{a}$ \\
\hline \multicolumn{8}{|l|}{$\begin{array}{l}\text { 22. Use questions to stimulate different kinds } \\
\text { of student learning. }\end{array}$} \\
\hline & Mean & 3.6705 & 3.8933 & 4.3580 & 4.1509 & 3.5492 & 3.4468 \\
\hline & $S D$ & .8540 & .8475 & .6578 & .7941 & $\mathrm{n} / \mathrm{a}$ & $\mathrm{n} / \mathrm{a}$ \\
\hline \multicolumn{8}{|l|}{$\begin{array}{l}\text { 23. Help students learn to think critically and } \\
\text { solve problems. }\end{array}$} \\
\hline & Mean & 3.4205 & 3.7333 & 4.0741 & 4.0189 & 3.4417 & 3.2766 \\
\hline & $S D$ & .7539 & .7769 & .6280 & .7719 & $\mathrm{n} / \mathrm{a}$ & $\mathrm{n} / \mathrm{a}$ \\
\hline \multicolumn{8}{|l|}{$\begin{array}{l}\text { 24. Encourage students to see, question, and } \\
\text { interpret ideas from diverse perspectives. }\end{array}$} \\
\hline & Mean & 3.2727 & 3.5333 & 4.0617 & 3.8868 & 3.3834 & 3.2609 \\
\hline & $S D$ & .8674 & .8275 & .6954 & .8242 & $\mathrm{n} / \mathrm{a}$ & $\mathrm{n} / \mathrm{a}$ \\
\hline \multicolumn{8}{|l|}{ Use Technology } \\
\hline 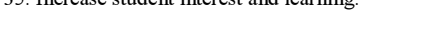 & Mean & 3.2500 & 3.4933 & 3.6667 & 3.2264 & 2.9573 & 2.7826 \\
\hline & $S D$ & .9619 & .8281 & 1.0607 & .9931 & $\mathrm{n} / \mathrm{a}$ & $\mathrm{n} / \mathrm{a}$ \\
\hline \multicolumn{8}{|l|}{$\begin{array}{l}\text { 36. Support research and analysis (i.e., } \\
\text { accessing the internet.) }\end{array}$} \\
\hline & Mean & 3.3409 & 3.5867 & 3.8765 & 3.6226 & 2.5892 & 2.5217 \\
\hline & $S D$ & 1.0492 & .9739 & 1.0171 & 1.0782 & $\mathrm{n} / \mathrm{a}$ & $\mathrm{n} / \mathrm{a}$ \\
\hline \multicolumn{8}{|l|}{ 37. Assess and track student achievement. } \\
\hline & Mean & 3.5455 & 3.6933 & 3.6420 & 3.4340 & 2.6901 & 2.7174 \\
\hline & $S D$ & 1.0711 & 1.0131 & 1.0162 & .8882 & $\mathrm{n} / \mathrm{a}$ & $\mathrm{n} / \mathrm{a}$ \\
\hline \multicolumn{8}{|l|}{$\begin{array}{l}\text { 38. Communicate with others (in school, } \\
\text { city, state, country, and world). }\end{array}$} \\
\hline & Mean & 3.7841 & 3.8400 & 4.1358 & 3.8868 & 2.7185 & 2.8478 \\
\hline & $S D$ & 1.0875 & .9869 & .9454 & .9739 & $\mathrm{n} / \mathrm{a}$ & $\mathrm{n} / \mathrm{a}$ \\
\hline \multicolumn{8}{|l|}{ 39. Enhance group collaboration and teamwork. } \\
\hline & $S D$ & .9767 & 1.0279 & .9023 & 1.1473 & $\mathrm{n} / \mathrm{a}$ & $\mathrm{n} / \mathrm{a}$ \\
\hline \multicolumn{8}{|l|}{$\begin{array}{l}\text { Understand Learners } \\
\text { 11. Understand how students' social, emotional, } \\
\text { physical, and cognitive development influences } \\
\text { learning. }\end{array}$} \\
\hline & Mean & 2.9886 & 3.7867 & 4.0617 & 3.7736 & 3.7080 & 3.5833 \\
\hline & $S D$ & 1.0114 & .8898 & .7305 & 1.0123 & $\mathrm{n} / \mathrm{a}$ & $\mathrm{n} / \mathrm{a}$ \\
\hline \multicolumn{8}{|l|}{$\begin{array}{l}\text { 12. Understand how students' family and } \\
\text { cultural backgrounds may influence learning. }\end{array}$} \\
\hline & Mean & 3.2273 & 3.7600 & 4.1481 & 3.9057 & 3.6495 & 3.4042 \\
\hline \multirow{3}{*}{$\begin{array}{l}\text { 13. Identify and address special learning needs } \\
\text { and/or difficulties. }\end{array}$} & $S D$ & .9794 & .7683 & .7601 & .9254 & $\mathrm{n} / \mathrm{a}$ & $\mathrm{n} / \mathrm{a}$ \\
\hline & Mean & 2.4545 & 3.9733 & $* * 3.5556$ & 3.0000 & 3.1032 & 2.6383 \\
\hline & $S D$ & .7865 & .6556 & $\begin{array}{r}.8515 \\
p=.001\end{array}$ & .8771 & $\mathrm{n} / \mathrm{a}$ & \\
\hline
\end{tabular}


Appendix B (continued)

\begin{tabular}{lcccccc}
\multicolumn{1}{c}{ Survey Item } & ACE & ACE & ACE & ACE & NYC & NYC \\
& 0.5 years & 1.5 years & $\leq 3$ years & $\geq 4$ years & $\leq 3$ years & $\leq 3$ years \\
& M.Ed. & M.Ed. & Post M.Ed. Post M.Ed. & Program Alternative \\
When you first started teaching, & Cohort 10 & Cohort 9 & Cohorts 6-8 Cohort 1-5 & Prepared Route Teachers \\
how well prepared did you feel to do the following: & $(N=88)$ & $(N=75)$ & $(N=81)$ & $(\mathrm{N}=56)$ & $(N=1,307)$ & $(N=48)$ \\
\hline
\end{tabular}

26. Understand how factors in the students' environment outside of school may influence their life and learning.

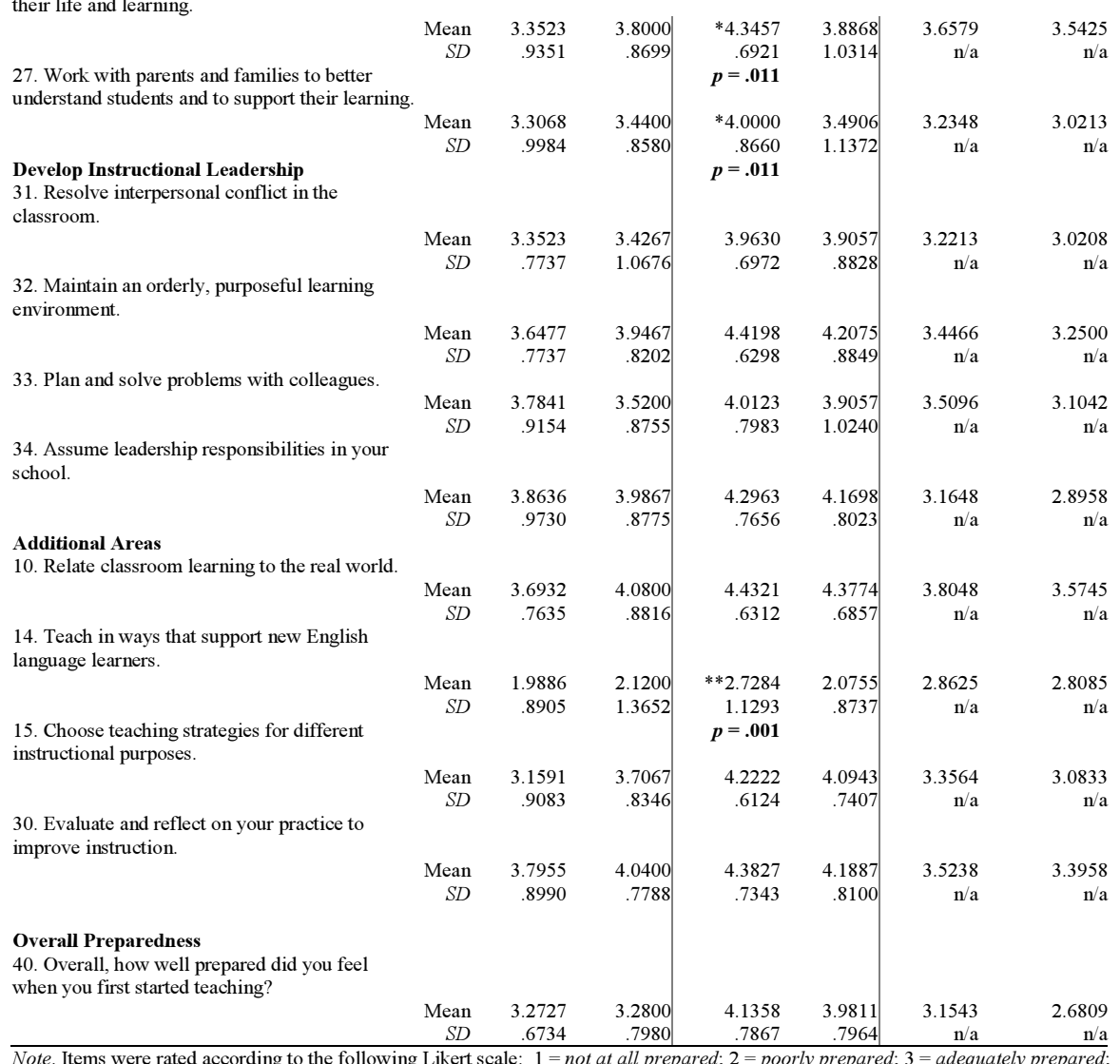

Note. Items were rated according to the following Likert scale: $1=$ not at all prepared; $2=$ poorly prepared; $3=$ adequately prepared; $4=$ well prepared $;=$ very well prepared. Standard Deviations were not provided in the primary source for the New York City data. NYC data source: Darling-Hammond, L., Chung, R. \& Frelow, F. (2002). Variation in teacher preparation: How well do different pathways prepare teachers to teach? Journal of Teacher Education, 53(4), 286-302. Copyright 2002 by the American Association of Colleges for Teacher Education.

Statistical analysis of means was conducted between the graduated cohort groupings (cohorts 6-8 and 1-5) only. ${ }^{*} \mathrm{p}<.05 . * * \mathrm{p}<.01$ 


\section{Appendix C}

Professional Preparedness Ratings by Catholic and Public School Setting

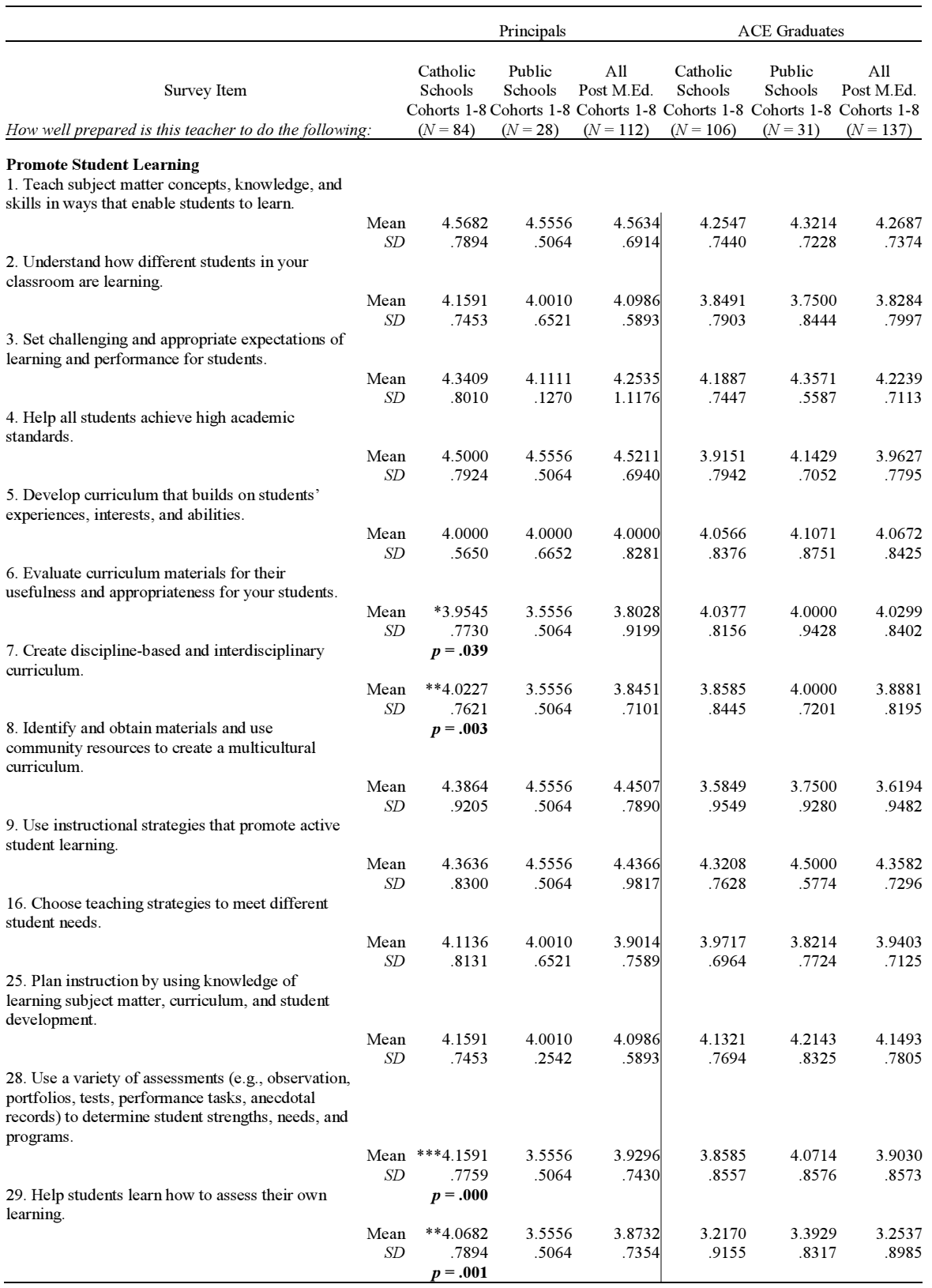


Appendix C (continued)

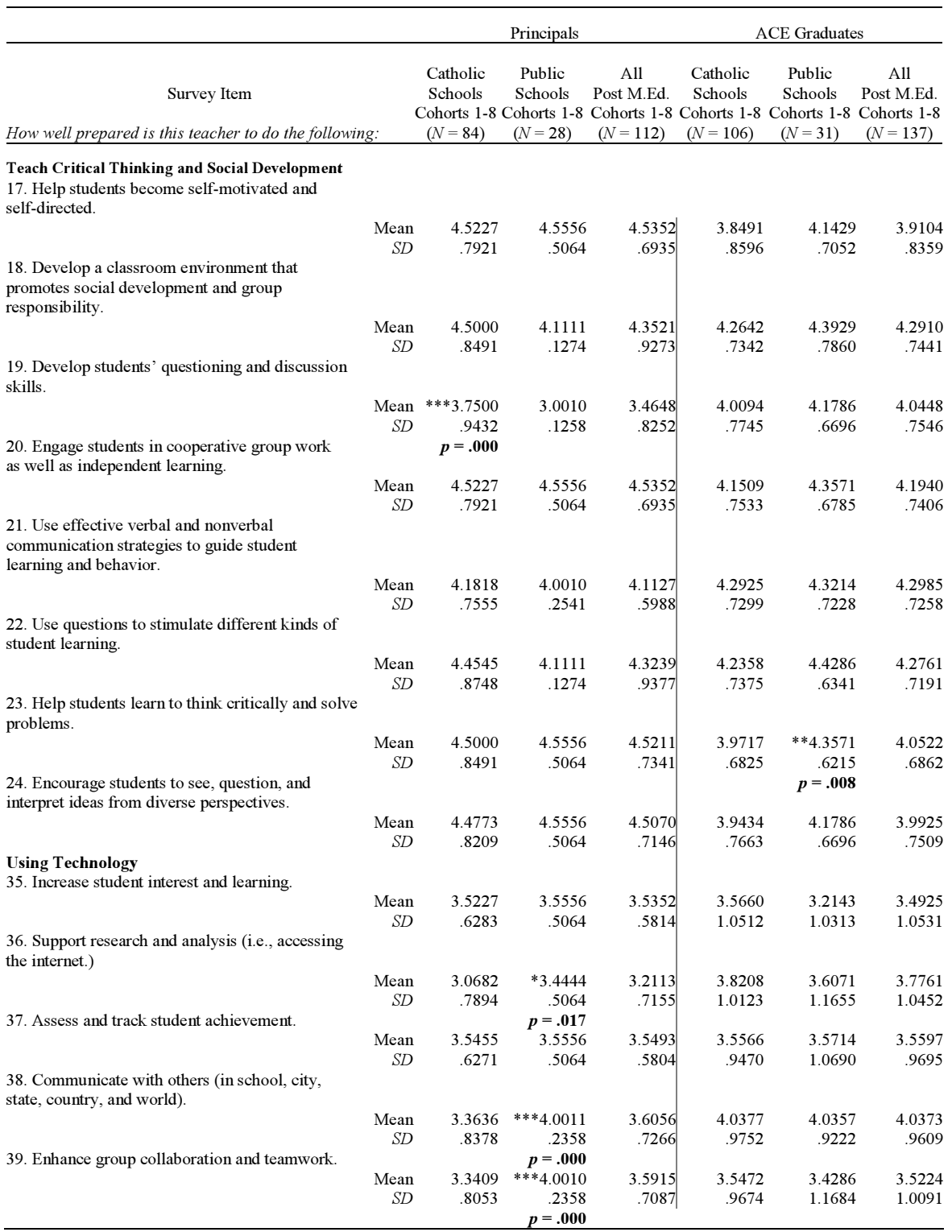


Appendix C (continued)

\begin{tabular}{ccccccc}
\hline & \multicolumn{3}{c}{ Principals } & & ACE Graduates \\
\hline & Catholic & Public & All & Catholic & Public & All \\
Survey Item & Schools & Schools & Post M.Ed. & Schools & Schools & Post M.Ed. \\
Cohorts 1-8 Cohorts 1-8 & Cohorts 1-8 & Cohorts 1-8 Cohorts 1-8 Cohorts 1-8 \\
$(N)$ & $(N=112)$ & $(N=106)$ & $(N=31)$ & $(N=137)$ \\
\hline
\end{tabular}

\section{Understand Learners}

11. Understand how students' social, emotional, physical, and cognitive development influences learning backgrounds may influence learning.

13. Identify and address special learning needs and/or difficulties.

26. Understand how factors in the students' environment outside of school may influence their life and learning.

27. Work with parents and families to better understand students and to support their learning.

\section{Develop Instructional Leadership}

31. Resolve interpersonal conflict in the classroom

32. Maintain an orderly, purposeful learning environment.

33. Plan and solve problems with colleagues.

34. Assume leadership responsibilities in your school.

\section{Additional Areas}

10. Relate classroom learning to the real world.

14. Teach in ways that support new English language learners.

15. Choose teaching strategies for different instructional purposes.

30. Evaluate and reflect on your practice to improve instruction.

\begin{tabular}{|c|c|c|c|c|c|c|}
\hline Mean & 4.0909 & .7414 & 4.0563 & 3.9434 & 3.9643 & 3.9478 \\
\hline$S D$ & 4.0001 & .4525 & .5828 & .8489 & .9222 & .8612 \\
\hline Mean & 4.1136 & 4.0011 & 4.0704 & 4.0377 & 4.1071 & 4.0522 \\
\hline$S D$ & .7538 & .4555 & .5934 & .8386 & .8317 & .8346 \\
\hline Mean & 3.2500 & 3.4444 & 3.3239 & 3.3868 & 3.1429 & 3.3358 \\
\hline$S D$ & .5757 & .5064 & .5548 & .8791 & .9705 & .9007 \\
\hline Mean & 3.9318 & 4.0010 & 3.9577 & 4.1604 & 4.1786 & 4.1642 \\
\hline$S D$ & .4354 & .3256 & .8183 & .8523 & .9449 & .8688 \\
\hline Mean & 3.8864 & 3.5556 & 3.7606 & 3.7547 & 3.9643 & 3.7985 \\
\hline$S D$ & .6135 & .5064 & .9018 & 1.0278 & .9616 & 1.0096 \\
\hline Mean & 4.1591 & 4.0011 & 4.0986 & 3.9057 & 4.0714 & 3.9403 \\
\hline$S D$ & .7453 & .2236 & .5893 & .7871 & .7164 & .7732 \\
\hline Mean & 4.3409 & 4.1111 & 4.2535 & 4.2925 & 4.5000 & 4.3358 \\
\hline$S D$ & .1997 & .1274 & 1.1303 & .7803 & .5774 & .7454 \\
\hline Mean & 4.1818 & 4.4444 & 4.2817 & 3.9528 & 4.0357 & 3.9701 \\
\hline$S D$ & .7555 & .5064 & .6800 & .9090 & .8381 & .8922 \\
\hline Mean & 3.9773 & 4.0010 & 3.9859 & 4.2170 & 4.3571 & 4.2463 \\
\hline$S D$ & .8888 & .2359 & .8534 & .7685 & .8262 & .7798 \\
\hline Mean & 4.1818 & 4.0010 & 4.1127 & 4.3679 & 4.5714 & 4.4104 \\
\hline$S D$ & .7555 & .5214 & .5988 & .6666 & .5727 & .6513 \\
\hline Mean & 3.0682 & 3.0010 & 3.0423 & 2.5094 & 2.3214 & 2.4701 \\
\hline$S D$ & .3339 & .4558 & .2639 & 1.0976 & 1.0203 & 1.0809 \\
\hline Mean & 4.5000 & 4.1111 & 4.3521 & 4.1981 & 4.0714 & 4.1716 \\
\hline$S D$ & .8491 & .1274 & .9273 & .6535 & .7164 & .6663 \\
\hline Mean & 4.0010 & $* 4.4444$ & 4.1690 & 4.2264 & $* 4.6071$ & 4.3060 \\
\hline$S D$ & .9974 & .5064 & .9409 & .7962 & .5669 & .7680 \\
\hline & & $p=.024$ & & & $p=.019$ & \\
\hline Mean & 3.9773 & 4.0011 & 3.9859 & 4.0472 & 4.1786 & 4.0746 \\
\hline$S D$ & .6721 & .2596 & .8365 & .8438 & .5480 & .7912 \\
\hline
\end{tabular}

Overall Preparedness

40. Overall, how well prepared did you feel when you first started teaching?

Note. Items were rated according to the following Likert scale: $1=$ not at all prepared; $2=$ poorly prepared; $3=$ adequately prepared $4=$ well prepared $5=$ very well prepared . $* p<.05 . * * p<.01 . * * * p<.001$. 